\title{
Pengembangan keterampilan pemodelan matematis bagi calon guru IPA
}

\author{
Wahono Widodo, Dhita Ayu Permata Sari *, Totok Suyanto, Martini Martini, Inzanah Inzanah \\ Universitas Negeri Surabaya. Kampus Ketintang Surabaya, 60231, Indonesia. \\ * Coressponding Author. E-mail: dhitasari@unesa.ac.id
}

Received: 11 September 2019; Revised: 5 March 2020; Accepted: 15 September 2020

\begin{abstract}
Abstrak: Tingkat keterampilan pemodelan matematis di kalangan mahasiswa calon guru IPA perlu ditingkatkan. Pada penelitian ini pengembangan keterampilan pemodelan matematis dilakukan dengan mengaplikasikan model pembelajaran ALLR (activity based, lesson learned, reflection) dalam kegiatan perkuliahan. Penelitian ini dilakukan dengan dua tahap, yaitu tahap persiapan (penyusunan buku model pembelajaran ALLR dan perangkat pembelajaran yang kemudian divalidasi dengan kategori valid) dan tahap penerapan pada Mata Kuliah Dasar-dasar IPA, khususnya materi pegas dan getaran dengan menggunakan desain one shot case study. Subjek penelitian ini adalah mahasiswa calon guru IPA PTN di Jawa Timur Indonesia yang berjumlah 28 mahasiswa. Teknik pengumpulan data dengan menggunakan tes dan rubrik. Data yang diperoleh kemudian dianalisis secara deskriptif kuantitatif dengan representasi yang berupa tabel yang memuat nilai ratarata, SD, persentase ketuntasan terhadap KKM, dan deskripsi dalam bentuk histogram. Hasil penelitian menunjukkan bahwa Model pembelajaran ALLR dapat digunakan untuk mengembangkan keterampilan matematis bagi calon guru IPA. Adapun saran yang disampaikan adalah keterampilan pemodelan matematis ini masih perlu terus dilatihkan pada berbagai MK yang relevan dengan model pembelajaran ALLR.
\end{abstract}

Kata Kunci: Model pembelajaran ALLR, pemodelan matematis

\section{Developing of mathematical modelling skills for science pre-service teachers}

Abstract: Mathematical modelling skills level of pre service teachers needs to be improved. This study aimed to develop pre service teachers' mathematical modelling skills by applying the ALLR (activity based, lesson learn, and reflection) learning model. This study was conducted in two stages, namely preparation stage and application stage. The first stage was the stage to prepare the ALLR learning model book, lesson plan, and student worksheet which have a valid category. Second stage was applied the lesson plan and the students worksheet using ALLR learning model to enhance mathematical modelling skills in the Basic Science Course. The topic discussed in this course was spring and vibration. The design of this study was one shot case study design. The subjects were 28 pre-service teachers of East Java, Indonesia. Data were collected by giving a test and rubrics. Then, the data were analysed descriptively and quantitatively in the form of table consist of the students' achievement. The results showed that the lesson plan and student worksheet applied using ALLR learning model improved pre-service teachers' mathematical modelling skills. It is suggested that mathematical modelling skills need to be trained in many other courses by applying ALLR learning model. Keywords: the ALLR learning model, mathematical modelling.

How to Cite: Widodo, W., Sari, D., Suyanto, T., Martini, M., \& Inzanah, I. (2020). Pengembangan keterampilan pemodelan matematis bagi calon guru IPA. Jurnal Inovasi Pendidikan IPA, 6(2), 146-155. doi:https://doi.org/10.21831/jipi.v6i2.27042

\section{PENDAHULUAN}

Kemajuan teknologi, inovasi ilmiah, globalisasi, tuntutan kualitas tenaga kerja yang semakin tinggi, dan tekanan daya saing ekonomi, menuntut guru tidak terkecuali adalah guru IPA untuk mampu mencetak generasi yang kreatif, solutif, dan dapat berpartisipasi serta berkontribusi pada kehidupan masyarakat saat ini (Levy \& Murnane, 2005; Stewart, 2010; Wilmarth, 2010). Di abad ini, keahlian individu lebih difokuskan pada pengembangan kapasitas pengetahuan yang dapat diterapkan secara luas, kebiasaan berpikir, dan mempersiapkan pengetahuan pekerja untuk perekonomian baru (Windschitl, 2009).

IPA pada hakekatnya merupakan sekumpulan pengetahuan, cara berpikir, tubuh pengetahuan, berkaitan erat dengan teknologi dan masyarakat, serta cara penyelidikan tentang alam semesta serta 
hubungannya dengan fakta-fakta yang ada (Bobrowsky, 2007; Collete \& Chiappetta, 1994; Koballa \& Chiappetta 2010). IPA terdiri dari empat aspek, yaitu sebagai produk ilmiah, proses ilmiah, sikap ilmiah, dan aplikasi ilmiah (Carin \& Sund, 1989; Koballa \& Chiappetta, 2010). IPA terbagi menjadi dua kelompok yaitu ilmu alam (the physical sciences) dan ilmu hayat (the biological sciences) (Suriasumantri, 2010). Ilmu alam ialah ilmu yang mempelajari zat yang membentuk alam semesta yang kemudian bercabang lagi menjadi fisika, kimia, astronomi, dan geologi. Sedangkan ilmu hayat mempelajari makhluk hidup (biologi). Dalam pengaplikasiannya, pembelajaran IPA diharapkan dapat menjadi wahana bagi siswa untuk mempelajari diri sendiri, alam sekitar, dan menerapankannya dalam menyelesaikan permasalahan dalam kehidupan (Diamond, 2011).

Guru merupakan unsur manusiawi yang sangat menentukan keberhasilan pendidikan (Bafadal, 2006). Mengembangkan pengetahuan epistemik pada mahasiswa calon guru IPA merupakan bagian penting dari pendidikan IPA (Elby, Macrander, \& Hammer, 2016; Lederman, Antink, \& Bartos, 2014). Pengetahuan epistemik mengacu pada pemahaman tentang peran khusus yang digunakan untuk merekonstruksi dan mendefiisikan hal-hal penting dalam membangun proses pengetahuan terhadap sains (Duschl, 2007). Pengetahuan epistemik memiliki kompetensi dalam mengevaluasi dan merancang inkuiri ilmiah serta menafsirkan data dan bukti ilmiah (OECD, 2016). Pengetahuan ini bergantung pada pemahaman tentang bagaimana pengetahuan ilmiah dibangun dan memegang tingkat kepercayaan pengetahuan ilmiah. Mahasiswa yang memiliki pengetahuan epistemik dapat menjelaskan dengan memberikan contoh-contoh; membedakan antara teori ilmiah, hipotesis, dan observasi; serta mengetahui bahwa model, representasi, abstrak atau matematis merupakan kunci utama sains (OECD, 2016).

Penelitian sebelumnya menunjukkan bahwa mahasiswa memiliki alternatif pengetahuan epistemik yang berbeda dengan para ahli. Mahasiswa kurang memahami peran ide dan teori dalam pembangun sifat sains. Mereka lebih suka melakukan kegiatan penyelidikan daripada membuat abstraksi teori untuk menjelaskan fenomena alam (Carey, Evans, Honda, Jay, \& Unger, 1989; Chinn \& Malhotra, 2002; Chuy et al., 2010; Sandoval, 2003). Padahal tugas penting seorang pendidik IPA ialah membantu peserta didik mengembangkan keterampilan berpikir para ilmuwan (Roth \& Roychoudhury, 1993).

Dalam konteks peyiapan guru IPA, khususnya IPA-Fisika, maka pola pikir dan pengetahuan epistemik tersebut harus dikembangkan. Salah satu pengetahuan epistemik yang dapat dibentuk pada mahasiswa calon guru IPA adalah keterampilan pemodelan matematis. Karena pada hakikatnya, di dalam IPA-fisika, ilmuwan berusaha memahami alam dengan membuat hubungan matematis antara gejala satu dengan yang lain. Sebagai contoh, hukum II Newton yang menjelaskan bagaimana keterkaitan antara gaya yang bekerja pada suatu benda dengan percepatan yang terjadi padanya.

Para ilmuwan menggunakan model dalam proses penyelidikan ilmiah dan mengembangkan model sebagai produk penyelidikan (Gilbert, 1991, 2004). Model merupakan representasi yang berfungsi untuk menggambarkan, menjelaskan, atau memprediksi (NRC, 1996; Van Driel \& Verloop, 1999). Model dapat merepresentasikan berbagai fenomena termasuk objek, abstraksi, sistem dan bagian dari sistem, entitas, hubungan antara entitas, peristiwa, perilaku, dan proses (Tregidgo \&Ratcliffe, 2000; Gilbert, 2004). Model merupakan tiruan yang disederhanakan yang diharapkan dapat digunakan untuk memahami sesuatu dengan lebih baik (Rutherford dan Ahlgren, 1990). Model bisa berupa matematik atau grafik (Butterworth dan Thwaites, 2005). Pada penelitian ini, model difokuskan pada pemodelan matematis.

Dalam pemodelan matematis, keterkaitan model yang digunakan tidak hanya dalam ruang lingkup matematika saja, tetapi juga berkaitan dengan disiplin ilmu yang lain (Rachmawati, 2013). Model matematika digunakan dalam banyak disiplin ilmu dan bidang studi yang berbeda seperti fisika, ilmu biologi dan kedokteran, teknik, ilmu sosial dan politik, ekonomi, bisnis dan keuangan, juga problem-problem jaringan komputer (Widowati \& Sutimin, 2007).

Pemodelan matematis di dalam fisika dapat diartikan sebagai konstruksi matematis yang digunakan untuk menjelaskan gejala fisis. Tujuan utama dari pemodelan ini adalah untuk menemukan penjelasan yang dapat mendiskripsikan berbagai fenomena yang berbeda, membuat prediksi, dan memandu ke arah pemahaman yang lebih baik terhadap alam (Zitzewitz, 1999). Sebagai contoh, model matematis untuk mengungkapkan keterkaitan hubungan panjang lintasan, kecepatan, dan waktu dari suatu benda yang bergerak, secara matematis dapat dituliskan $\mathrm{S}=\mathrm{v} \times \mathrm{t}$. Terdapat dua sifat pemodelan matematis, yaitu bersifat deduktif, yaitu berangkat dari sesuatu yang umum ke khusus (misalnya: Einstein menurunkan model matematis keterkaitan antara massa dan energi secara deduktif dari postulat 
Jurnal Inovasi Pendidikan IPA, 6 (2), 2020 - 148

Wahono Widodo, Dhita Ayu Permata Sari, Totok Suyanto, Martini Martini, Inzanah Inzanah

relativitas khusus). Sifat yang kedua adalah induktif, yaitu berangkat dari sesuatu yang khusus ke umum (misalnya dari penyelidikan, pengukuran variabel, lalu diabstraksikan hubungan antar variabelnya).

Tingkat keterampilan pemodelan matematis di kalangan mahasiswa, masih berada dalam kategori cukup dan rendah sehingga perlu ditingkatkan. Sebagaimana penelitian yang dilakukan oleh Sudarmin (2006) yang menyatakan bahwa kemampuan generik yang menuntut keterampilan berpikir tingkat tinggi, berabstraksi, dan mencari pola aturan suatu fenomena gejala alam umumnya memiliki tingkat pencapaian cenderung cukup dan rendah. Hal senada juga dipaparkan oleh Rahman (2016), yang mengungkapkan bahwa kemampuan generik pemodelan yang dicapai mahasiswa calon guru tergolong kategori rendah (rerata $=54,0$ ). Kemampuan ini meliputi membuat tabulasi, spesifikasi alat dan bahan, membuat prosedur praktikum dalam bentuk diagram panah dilengkapi gambar dan label.

Beberapa penelitian terkait pemodelan matematis diantaranya adalah penelitian Gunawan (2009) yang menemukan bahwa model multimedia interaktif dalam pembelajaran fisika dasar dapat meningkatkan keterampilan generik sains mahasiswa calon guru. Sejalan dengan hal tersebut, Widodo (2011) menggunakan model MiKiR untuk meningkatkan keterampilan generik sains mahasiswa. Salah satu bagian dari keterampilan generik sains adalah pemodelan matematis. Berdasarkan hasil penelitiannya, diketahui bahwa model ini memerlukan pengembangan Multimedia Interaktif. Dalam penelitainnya lebih lanjut, Gunawan (2013) yang menggunakan model virtual laboratory fisika modern untuk meningkatkan keterampilan generik sains calon guru, menemukan bahwa model virtual laboratory yang dikembangkan efektif meningkatkan keterampilan generik sains calon guru. Hartono (2006) menyatakan bahwa pengamatan tak langsung, kesadaran akan skala besaran, inferensi logika, hubungan sebab akibat, dan pemodelan matematika mampu membangun konsep pada pembelajaran fisika modern.

Tiga dari empat contoh penelitian terdahulu yang telah dipaparkan tersebut, sama-sama menggunakan media yang berbasis komputer untuk meningkatkan keterampilan pemodelan matematis mahasiswa calon guru dalam cakupan keterampilan generik sains. Sedangkan pada penelitian ini pengembangan keterampilan pemodelan matematis dilakukan dengan mengaplikasikan model pembelajaran ALLR (activity based, lesson learned, reflection) dalam kegiatan perkuliahan. Dalam proses pelaksanaannya, mahasiswa melakukan penyelidikan hubungan antar variabel dengan menggunakan lembar kegiatan mahasiswa (LKM) yang berbasis pada model pembelajaran ALLR. Penyelidikan yang dilakukan adalah dengan mengamati gaya yang bekerja pada pegas dan perubahan panjang pegas akibat gaya itu di dalam LKM, mahasiswa dapat membangun model matematis hubungan antara gaya dengan pertambahan panjang pada pegas. Selain itu, mahasiswa juga diberikan tes di akhir kegiatan perkuliahan untuk mengetahui keterampilan pemodelan matematis mahasiswa setelah mengikuti kegiatan perkuliahan dengan menggunakan model pembelajaran tersebut.

\section{METODE}

Penelitian ini dilakukan dengan dua tahap, yaitu tahap persiapan dan tahap penerapan. Pada tahap persiapan dilakukan penyusunan buku model pembelajaran ALLR dan perangkat pembelajaran yang meliputi Rencana Pembelajaran Semester (RPS), LKM, dan instrumen tes pemodelan matematis yang kemudian divalidasi dengan kategori valid. Pada tahap penerapan, perangkat pembeajaran tersebut diterapkan pada Mata Kuliah Dasar-dasar IPA, khususnya materi pegas dan getaran dengan menggunakan desain one shot case study.

Dalam penelitian ini, tidak ada kelompok kontrol dan subyek dalam penelitian ini diberi perlakuan (treatment) yaitu pembelajaran dengan menggunakan model ALLR. Kemudian di dalam proses pembelajaran, mahasiswa diberi LKM "Pemodelan Matematis dalam IPA (Kasus Pengaruh Gaya terhadap Pertambahan Panjang Pegas)". Selanjutnya, di akhir kegiatan pembelajaran, mahasiswa diberikan tes dengan konteks yang menghasilkan pemodelan matematis yaitu materi "Tegangan Listrik".

Subjek penelitian ini adalah mahasiswa calon guru IPA PTN di Jawa Timur Indonesia yang berjumlah 28 mahasiswa. Teknik pengumpulan data dengan menggunakan tes dan rubrik. Penilaian dilakukan dengan mencocokkan antara jawaban mahasiswa dengan rubrik penilaian. Data yang diperoleh kemudian dianalisis secara deskriptif kuantitatif dengan representasi yang berupa tabel berupa tabel yang memuat nilai rata-rata, standar deviasi, persentase ketuntasan terhadap KKM, dan deskripsi dalam bentuk histogram.

\section{HASIL DAN PEMBAHASAN}


Saglam (2004) mencatat bahwa, terdapat dua pendekatan yang dapat diaplikasikan untuk mengembangkan keterampilan pemodelan matematis, yaitu pendekatan eksperimental dan pendekatan teoretis. Pendekatan eksperimental didasarkan pada data percobaan dan pendekatan teoretis didasarkan pada hukum yang diperoleh secara fisik model (Guillon, 1995).

Pada penelitian ini, pendekatan yang digunakan adalah pendekatan ekperimental. Pengembangan keterampilan pemodelan matematis bagi calon guru IPA dilakukan dengan mengaplikasikan model pembelajaran ALLR yang sebelumnya dikembangkan. Model Pembelajaran ALLR menekankan pada aktivitas mahasiswa yang memadukan dan menyeimbangkan antara aspek koginitif, afektif, dan psikomotor sekaligus mendorong mahasiswa untuk memaknai dan mengambil hikmah serta memberikan ruang bagi mahasiswa untuk melakukan refleksi (Widodo, 2018). Model pembelajaran ALLR yang diterapkan dengan menggunakan Lembar Kerja Mahasiswa didesain untuk meningkatkan keterampilan proses mahasiswa sekaligus karakter mahasiswa (Widodo, 2019). Sintaks model pembelajaran ALLR adalah (1) mengorientasikan mahasiswa pada fenomena yang akan diselidiki atau masalah yang hendak diselesaikan, (2) merancang proses penyelidikan atau penyelesaian masalah, (3) membimbing penyelidikan atau penerapan metode penyelesaian masalah secara berkelompok, (4) mengembangkan dan mempresentasikan hasil penyelidikan atau penyelesaian masalah, (5) pengambilan hikmah, dan (6) refleksi (Widodo, 2018).

Dalam proses pelaksanaannya, mahasiswa melakukan penyelidikan dengan menggunakan LKM dan di akhir perkuliahan mahasiswa diberikan tes utuk mengetahui keterampilan pemodelan matematis mahasiswa. Berdasarkan kegiatan penelitian tersebut diperoleh data sebagai berikut:

\section{Data Proses Pemodelan Matematis setelah Mengerjakan LKM dengan Model Pembelajaran ALLR}

Data proses pemodelan matematis diperoleh dari nilai mahasiswa setelah mengerjakan LKM yang berbasis model ALLR. LKM yang diberikan pada mahasiswa berisi kegiatan eksperimental dengan tujuan agar mahasiswa mampu membuat model matematis pengaruh gaya terhadap pertambahan panjang pegas secara berkelompok. Gambar 1 merupakan salah satu contoh hasil pengerjaan LKM.

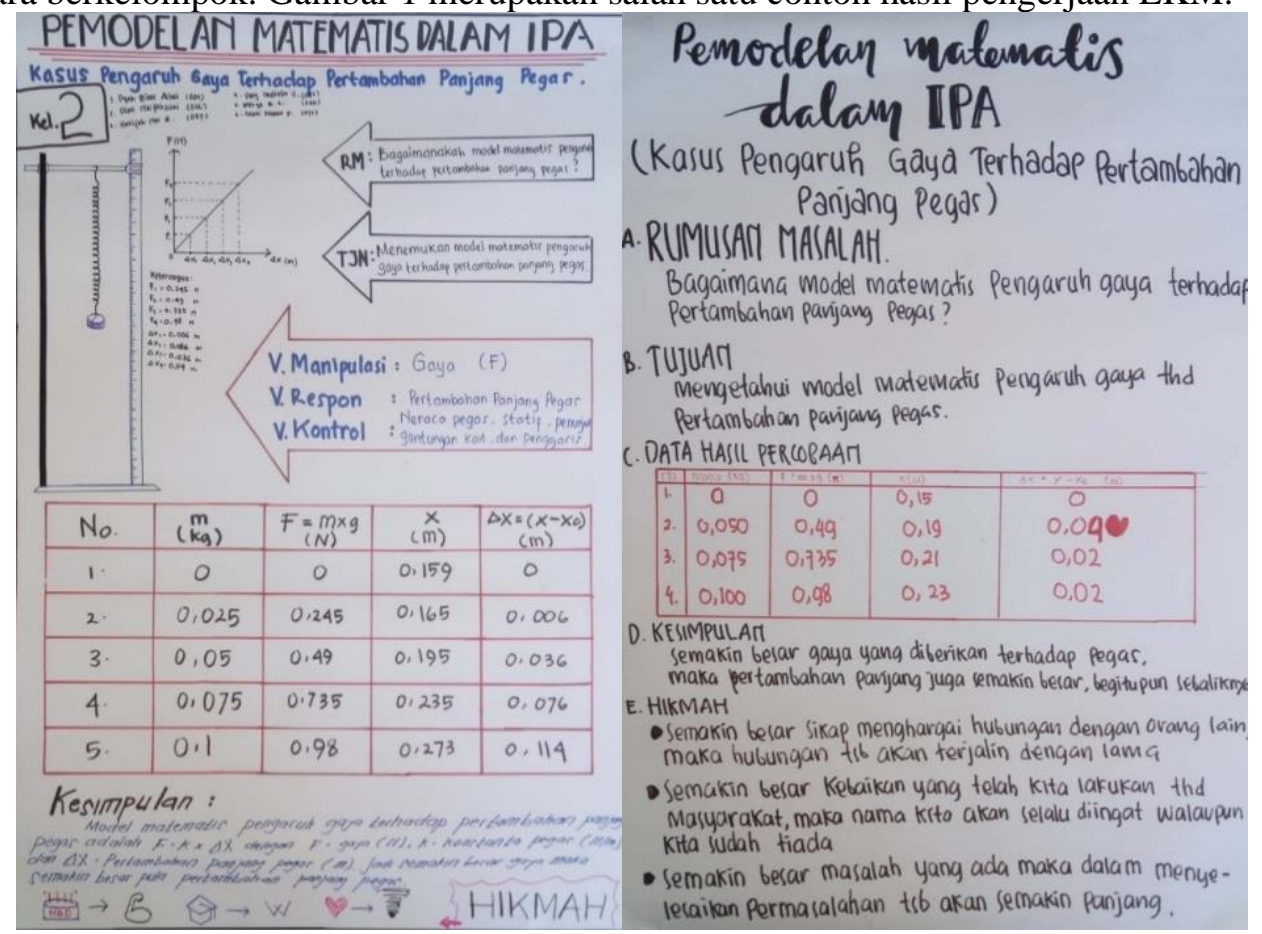

Gambar 1. Hasil Pengerjaan LKM

Adapun kegiatan eksperimental yang dilakukan mahasiswa dalam LKM tersebut adalah: (a) menuliskan rumuskan masalah, (b) merumuskan tujuan percobaan, (c) mencatat data hasil percobaan, (d) mengabstraksi hubungan matematis antara dua variabel berdasarkan hasil pengukuran, dan (e) menulis hikmah yang merupakan ciri khas dari model pembelajaran ALLR. Data hasil pengerjaan LKM disajikan pada Tabel 1. 
Jurnal Inovasi Pendidikan IPA, 6 (2), 2020 - 150

Wahono Widodo, Dhita Ayu Permata Sari, Totok Suyanto, Martini Martini, Inzanah Inzanah

Tabel 1. Nilai Proses Pemodelan Matematis Mahasiswa

\begin{tabular}{|c|c|c|c|c|}
\hline No. & Item Soal & Nilai Rata-rata & $\%$ Ketuntasan dengan KKM & \\
\hline 1. & $\mathrm{a}$ & 92 & 100 & \\
\hline 2. & $\mathrm{~b}$ & 92 & 100 & \\
\hline 3. & $\mathrm{c}$ & 100 & 100 & \\
\hline 4. & d & 100 & 100 & \\
\hline 5. & $\mathrm{e}$ & 100 & 100 & \\
\hline \multicolumn{2}{|c|}{ Rata-rata } & 96.80 & & \\
\hline \multicolumn{3}{|c|}{$\%$ Ketuntasan Klasikal } & & 100 \\
\hline \multicolumn{3}{|c|}{ Nilai Min } & & 75 \\
\hline \multicolumn{3}{|c|}{ Nilai Maks } & & 100 \\
\hline \multicolumn{3}{|l|}{ SD } & & 4.756 \\
\hline
\end{tabular}

Berdasarkan Tabel 1 dapat diketahui bahwa kegiatan mencatat data hasil percobaan, mengabstraksi hubungan matematis antara dua variabel berdasarkan hasil pengukuran, dan menulis hikmah, semua mahasiswa mendapatkan total nilai rata-rata yang sempurna yaitu 100 untuk tiap kegiatan eksperimentalnya. Sedangkan untuk kegiatan menuliskan merumuskan masalah dan merumuskan tujuan percobaan, total nilai rata-rata yang berhasil dicapai oleh mahasiswa masing-masing adalah 92 untuk tiap kegiatan eksperimentalnya. Adapun rata-rata nilai keseluruhan yang berhasil dicapai mahasiswa pada proses pemodelan matematis, yaitu sebesar 96,80. Berdasarkan nilai capaian tersebut diketahui bahwa tingkat perolehan mahasiswa pada sangat tinggi, baik dari segi proses pemodelan matematis secara induktif maupun secara klasikal.

Demikian halnya dengan persentase ketuntasan terhadap kriteria ketuntasan minimal $(\mathrm{KKM}=$ 66), semua mahasiswa dinyatakan tuntas baik secara proses pemodelan matematis secara induktif maupun secara klasikal. Hal tersebut terbukti dari perolehan nilai persentase yang sempurna, yaitu $100 \%$.

Tabel 1 memberikan informasi bahwa nilai minimal yang dicapai mahasiswa adalah 75, nilai maksimalnya 100, dan standar deviasinya (SD) adalah 4,756. Standar deviasi menunjukkan ukuran variansi data terhadap rata-rata. Standar deviasi dapat menggambarkan tingkat variasi data. Apabila nilai standar deviasi lebih besar daripada nilai rata-rata, berarti nilai rata-rata merupakan representasi yang buruk dari keseluruhan data. Begitu pula sebaliknya, apabila nilai standar deviasi lebih kecil daripada nilai rata-rata, berarti nilai rata-rata dapat digunakan sebagai representasi dari keseluruhan data. Dari tabel tersebut nampak bahwa SD lebih kecil dari nilai rata-ratanya. Hal ini berarti bahwa variansi data relatif lebih kecil dan nilai rata-rata yang diperoleh dapat digunakan sebagai representasi dari keseluruhan data.

Berdasarkan data pada Tabel 1, dapat dinyatakan bahwa perolehan rata-rata nilai yang berhasil dicapai, tidak terpaut jauh antara satu dengan yang lainnya. Hal tersebut dipengaruhi karena dalam proses pelaksanaannya, LKM dikerjakan secara berkelompok (kooperatif). Sebagaimana tujuan dari pembelajaran kooperatif adalah menciptakan situasi di mana keberhasilan individual ditentukan atau dipengaruhi oleh keberhasilan kelompoknya (Lundgren L., 1994).

Ketercapaian tersebut tidak terlepas dari pengaruh model pembelajaran yang digunakan, yaitu ALLR. ALLR adalah model pembelajaran yang menekankan pada aktifitas mahasiswa dengan memadukan dan menyeimbangkan antara aspek kognitif, afektif, psikomotor dan mendorong mahasiswa untuk dapat memaknai dan mengambil hikmah serta memberikan ruang yang luas bagi mahasiswa untuk memberikan refleksi terhadap kegiatan pembelajaran yang telah berlangsung (Widodo, dkk., 2018).

Model ALLR yang mengajarkan mahasiswa untuk memecahkan masalah dapat mendorong mahasiswa untuk membangun pemahaman konsep (Widodo, dkk, 2019). Konstruksi pemahaman konsep dapat terjadi melalui suatu proses menghubungkan pengetahuan dalam menyelesaikan masalah pembelajaran (Sadiqin, dkk, 2017). Kegiatan berbasis masalah juga efektif digunakan untuk meningkatkan kemampuan pemecahan masalah dan karakter pebelajar (Tivani dan Paidi, 2016).

Dalam model pembelajaran ALLR ini juga, dosen memfasilitasi mahasiswa agar menyelesaikan tugas dengan baik. Pendampingan ini memberikan kesempatan bagi mahasiswa untuk berdiskusi sekaligus mengevaluasi rencana kerjanya sebelum melakukan serangkaian kegiatan dalam memecahkan masalah. Hal inilah yang memungkinkan pencapaian belajar mahasiswa menjadi terarah dan sesuai dengan harapan. Hal serupa juga diungkapkan oleh Rahayu (2017) yang menyatakan bahwa pendampingan guru lebih meningkatkan pemahaman siswa terhadap materi pembelajaran. 
Pembelajaran yang aktif dapat meningkatkan interaksi dan taraf berfikir tingkat tinggi mahasiswa (Yerigan, 2008). Sejalan dengan hal tersebut, fokus utama pembelajaran dalam pendidikan tinggi ialah melibatkan mahasiswa secara aktif dalam proses pembelajaran (Kolb \& Kolb, 2005). Pembelajaran yang aktif juga akan memudahkan mahasiswa dalam menemukan berbagai konsep dan fakta ilmiah. Konsep dan fakta ilmiah yang ditemukan sendiri oleh mahasiswa akan lebih bertahan lama dalam memorinya dibandingkan dengan materi yang di suguhkan oleh dosen. Dengan pemahaman terhadap konsep dan fakta ilmiah inilah, mahasiswa dilatih untuk menerjemahkannya ke dalam bahasa matematis. Di sisi lain, keterampilan pemodelan matematik juga dapat dimanfaatkan pengajar untuk menjelaskan konsep dan fakta-fakta ilmiah.

\section{Data Hasil Pemodelan Matematis Hasil Tes Mahasiswa}

Data pemodelan matematis diperoleh dari nilai tes mahasiswa. Tes tersebut diberikan pada mahasiswa setelah mereka mengikuti pembelajaran dengan model ALLR. Dalam tes tersebut, dipaparkan konten yang berisi hasil pengamatan seseorang terhadap tegangan listrik yang dihasilkan oleh putaran kumparan (dengan jumlah lilitan yang bervariasi) yang didekatkan dengan magnet. Tes tersebut terdiri dari 5 item soal, yaitu (a) menuliskan rumusan masalah, (b) menentukan variabel, (c) menganalisis data dalam bentuk grafik, (d) menuliskan model matematis, dan (e) menuliskan hikmah berdasarkan hasil percobaan tersebut. Hasil tes pemodelan matematis dipaparkan pada Tabel 2.

Tabel 2. Nilai Pemodelan Matematis Mahasiswa

\begin{tabular}{|c|c|c|c|c|}
\hline No. & Item Soal & Nilai Rata-rata & $\%$ Ketuntasan dengan KKM & \\
\hline 1. & $\mathrm{a}$ & 99 & 100 & \\
\hline 2. & b & 88 & 86 & \\
\hline 3. & $\mathrm{c}$ & 97 & 100 & \\
\hline 4. & d & 61 & 39 & \\
\hline 5. & e & 94 & 100 & \\
\hline \multicolumn{2}{|c|}{ Rata-rata } & 87.80 & & \\
\hline \multicolumn{3}{|c|}{ \% Ketuntasan Klasikal } & & 96 \\
\hline \multicolumn{3}{|c|}{ Nilai Min } & & 25 \\
\hline \multicolumn{3}{|c|}{ Nilai Maks } & & 100 \\
\hline \multicolumn{3}{|l|}{ SD } & & 6.996 \\
\hline
\end{tabular}

Tabel 2 memberikan informasi nilai pemodelan matematis mahasiswa. Berdasarkan Tabel 2, diketahui bahwa rata-rata nilai tertinggi yang berhasil dicapai mahasiswa adalah sebesar 99 untuk item soal menuliskan rumusan masalah, disusul kemudian menganalisis data dalam bentuk grafik dengan nilai 97, dan menuliskan hikmah dengan nilai 94. Persentase persentase ketuntasan terhadap KKM untuk ketiga item soal tersebut adalah $100 \%$. Sedangkan pada item soal menentukan variabel percobaan, ratarata nilainya adalah 88 dengan persentase ketuntasan terhadap KKM adalah $86 \%$. Adapun nilai terendah yang dicapai mahasiswa adalah pada item soal menuliskan model matematis dengan nilai 61 (cukup) dengan persentase ketuntasan terhadap KKM relatif rendah apabila dibandingkan dengan yang lainnya, yaitu $39 \%$.

Salah satu faktor yang menyebabkan rendahnya nilai pada item soal menuliskan model matematis tersebut adalah belum terlatihnya mahasiswa dalam mengasosiasikan antara kasus fisika dengan pemodelan matematis. Hal tersebut sejalan dengan penelitian Buty (2000), yang menyatakan bahwa masalah utama siswa dalam proses pemodelan adalah mengasosiasikan hubungan antara model dengan situasi yang akan dimodelkan. Padahal untuk mempelajari fisika, siswa harus terlibat dalam semua aspek pemodelan (Hestenes, 1996). Di sisi lain, pemahaman lengkap tentang konsep dalam fisika membutuhkan kefasihan dalam bahasa matematika di mana konsep-konsep tersebut dikemas (Tuminaro and Redish, 2004).

Tabel 2 juga memberikan informasi bahwa rata-rata nilai keseluruhan yang berhasil dicapai mahasiswa pada proses pemodelan matematis, yaitu sebesar 87,80. Berdasarkan Buku Pedoman Akademik 2018/2019 Unesa, nilai tersebut berada pada kategori sangat baik (A) (Buku Pedoman Akademik Unesa, 2019). Adapun nilai minimal yang dicapai mahasiswa adalah 25 , nilai maksimalnya adalah 100 , dan SD adalah 6,996. Seperti halnya pada Tabel 1, bahwa SD yang dihasilkan lebih kecil dari nilai rata-ratanya. Hal ini berarti bahwa variansi data relatif lebih kecil dan nilai rata-rata yang diperoleh dapat digunakan sebagai representasi dari keseluruhan data. 
Jurnal Inovasi Pendidikan IPA, 6 (2), 2020 - 152

Wahono Widodo, Dhita Ayu Permata Sari, Totok Suyanto, Martini Martini, Inzanah Inzanah

Berdasarkan data pada Tabel 1 dan Tabel 2, disusunlah histogram yang menggambarkan rata-rata nilai keterampilan pemodelan matematis beserta Standar Deviasinya (SD) sebagaimana disajikan pada Gambar 2.

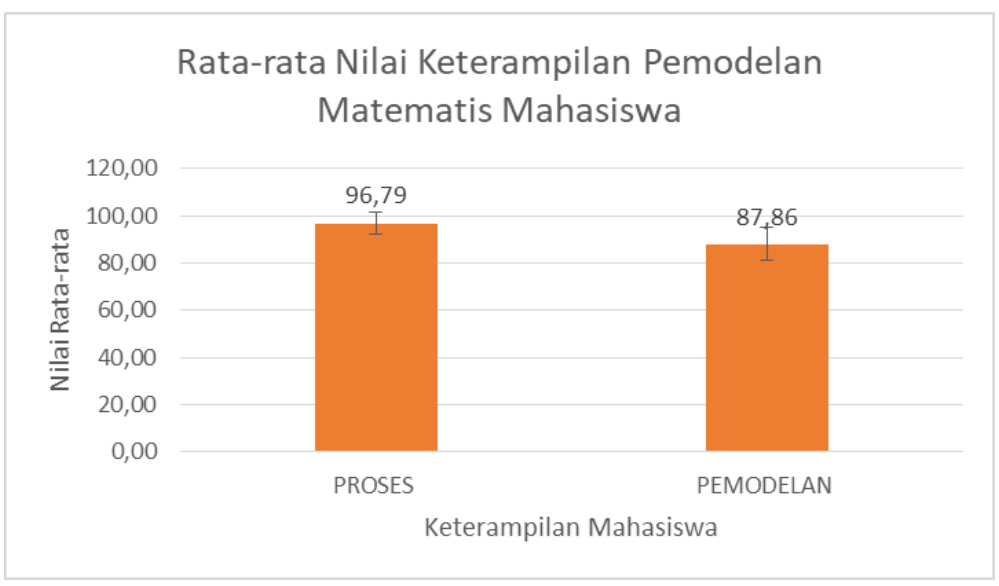

Gambar 2. Histogram Rata-rata Hasil Tes Pemodelan

Berdasarkan histogram pada Gambar 2, nampak bahwa capaian nilai rata-rata proses pemodelan matematis relatif lebih tinggi daripada nilai rata-rata pemodelan matematis mahasiswa. Demikian halnya dengan SD pada proses pemodelan matematis relatif rendah daripada SD pada pemodelan matematis mahasiswa. Walaupun demikian, nilai SD untuk kedua jenis penilaian lebih kecil dari nilai rata-ratanya. Hal ini berarti bahwa variansi data relatif lebih kecil dan nilai rata-rata yang diperoleh dapat digunakan sebagai representasi dari keseluruhan data.

Berdasarkan fakta-fakta tersebut, pokok penting yang harus diperhatikan dalam mengembangkan keterampilan pemodelan matematis adalah pengajar harus memahami hakikat fisika sebagai pemodelan, menjadi pemodel, dan penginterpretasi model. Model dan pemodelan mendapat perhatian yang meningkat dari komunitas pendidikan sains sebagai komponen penting dari pendidikan sains kontemporer (Gilbert, 2004; Gilbert \& Boulter, 2000; GIREP, 2006; Greca \& Moreira, 2002; Hestenes, 1987). Untuk menjadi pemodel yang kompeten, diperlukan latihan dalam proses penalaran. Hal tersebut dikarenakan penalaran merupakan perantara penting antara observasi eksperimental dan representasi konseptual (Angell et al., 2008).

Hal tersebut didukung oleh teori pembelajaran sosial yang dikemukakan oleh Bandura dan Walters (1977) meyakini bahwa segala sesuatu dapat dipelajari ketika pembelajar mengamati secara terus menerus terhadap suatu perilaku tertentu (model) dan kemudian meletakkan hasil pengamatan tersebut ke dalam memori jangka panjangnya. Menurut Bandura proses mengamati dan meniru perilaku dan sikap orang lain sebagai model merupakan tindakan belajar (Bandura \& Walters, 1977). Menurut banyak peneliti termasuk Chevallard (1989), Henry (2001), dan Borremeo (2006), menyatakan bahwa situasi yang akan dimodelkan dan model adalah salah satu langkah mendasar dari proses pemodelan.

\section{SIMPULAN}

Dalam konteks peyiapan guru IPA, khususnya IPA-Fisika, keterampilan pemodelan matematis perlu dikembangkan. Karena pada hakikatnya, di dalam IPA-fisika, ilmuwan berusaha memahami alam dengan membuat hubungan matematis antara gejala satu dengan yang lain. Pemodelan matematis sangat diperlukan untuk menemukan penjelasan yang dapat mendiskripsikan berbagai fenomena yang berbeda, membuat prediksi, dan memandu ke arah pemahaman yang lebih baik terhadap alam. Pada penelitian ini pengembangan keterampilan pemodelan matematis dilakukan dengan mengaplikasikan model pembelajaran ALLR pada MK Dasar-dasar IPA, khususnya materi pegas dan getaran. Dari hasil penelitian dapat disimpulkan bahwa model pembelajaran ALLR dapat digunakan untuk mengembangkan keterampilan matematis bagi calon guru IPA.

Secara keseluruhan, nilai yang berhasil dicapai mahasiswa adalah berada pada kategori baik dan sangat baik. Akan tetapi, apabila dilihat pada kemampuan menuliskan model matematis, mahasiswa masih perlu untuk terus dilatih. Dalam melatihkannyapun tidak cukup hanya dengan satu atau dua kali latihan saja, akan tetapi perlu pelatihan yang cukup intens sampai semua kategori dalam keterampilan 
tersebut benar-benar mampu dikuasai mahasiswa. Dalam pengaplikasiannya, keterampilan pemodelan matematis ini dapat dilatihkan pada berbagai MK yang relevan dengan model pembelajaran ALLR.

\section{UCAPAN TERIMA KASIH}

Kami mengucapkan terima kasih kepada Kementerian Riset dan Pendidikan Tinggi yang telah mendukung penelitian ini hingga naskah artikel ini ditulis. Kamu ucapkan terima kasih pula kepada rekanrekan di Jurusan IPA FMIPA Unesa yang membantu kegiatan penelitian ini.

\section{DAFTAR PUSTAKA}

Angell, C., Kind, P. M., Henriksen, E. K., \& Guttersrud, Ø. (2008). An empirical-mathematical modelling approach to upper secondary physics. Physics Education, 43(3), 256-264. https://doi.org/10.1088/0031-9120/43/3/001

Bafadal, I. (2006). Manajemen peningkatan mutu sekolah dasar: Dari sentralisasi menuju desentralisasi. Bumi Aksara.

Bandura, A., \& Walters, R. H. (1977). Social learning theory. Prentice-hall.

Butterworth, J., \& Thwaites, G. (2005). Thinking Skills. Cambridge: Cambridge

Bobrowsky, M. (2007.) The process of science and its interaction with non-scientific ideas. American Astronomical Society.

Borremeo FR. (2006). Theoretical and empirical differentiations of phases in the modelling process. Zentralblatt für Didaktik der Mathematik 38(2): 86-95.

Buty, C. (2000). Etude d'un apprentissage dans une sequence d'enseignement en optique géométrique à l'aide d'une modélisation informatique. Ph.D. Thesis, Université Lumière Lyon 2, Lyon, France.

Carey, S., Evans, R., Honda, M., Jay, E., \& Unger, C. (1989). An experiment is when you try it andsee if it works': A study of Grade 7 Students' Understanding of the Construction of Scientific Knowledge. International Journal of Science Education, 11 (5), 514-529.

Carin, A. A. \& Sund, R. B. (1989). Teaching Science through Discovery. Columbus: Merrill Publishing Company.

Chevallard Y. (1989). Le passage de l'arithmétique a l'algèbre dans l'enseignement des mathématiques au collège. Perspectives circulaires: La notion de modélisation. Petit X 19: 43-72

Chinn, C. A., \& Malhotra, B. A. (2002). Epistemologically authentic inquiry in schools: A theoretical framework for evaluating inquiry tasks. Science Education, 86 (2), 175-218.

Chuy, M., Scardamalia, M., Bereiter, C., Prinsen, F., Resendes, M., Messina, R., \& Angela Chow, T.C. Y. (2010). Understanding the nature of science and scientific progress: A theory building approach. Canadian Journal of Learning and Technology, 36 (1). Retrieved fromhttps://www.cjlt.ca/index.php/cjlt/article/view/26373/19555

Collette, A. T., \& Chiappetta, E. L. (1994). Science instruction in the middle and secondary schools. 2nd Edition. Macmillan Pub. Co.

Diamond, I. (2011). Science education in schools. TLRP Institute of Education University of London.

Duschl, R. (2007). Science education in three-part harmony: Balancing conceptual, epistemic, and social learning goals. Review of Research in Education, Vol. 32, pp. 268-291.

Elby, A., Macrander, C., \& Hammer, D. (2016). Epistemic cognition in science. In J. A. Greene, W.A. Sandoval, \& I. Bråten (Eds.). Handbook of Epistemic Cognition (pp. 113-127). New York, NY: Routledge.

Ergül. R, Şımşeklı. Y, Çaliş. S, Özdılek. Z, Göçmençelebı. Ş, \& Şanli. M. (2011). The effects of inquirybased science teaching on elementary school students' science process skills and science attitudes. Bulgarian Journal of Science \& Education Policy, 5 (1), pp. 48-68.

Gilbert, J. K. (1991). Model building and a definition of science. Journal of Research in Science Teaching, 28, 3-17.

Gilbert, J. K. (2004). Models and modeling: routes to more authentic science education, International Journal of Science and Mathematics Education, 2, 115-130. 
Gilbert, J. K., \& Boulter, C. (Eds.). (2000). Developing models in science education. Dordrecht: Kluwer. Girep. (2006). Modelling in physics and physics education. Online: http://www.girep2006.nl/. Diakses tanggal 2 September 2019.

Greca, I. M., \& Moreira, M. A. (2002). Mental, physical and mathematical models in the teaching and learning of physics. Science Education, 86, 106-121.

Guillon A. (1995). Démarches scientifiques en travaux pratiques de physique de DEUG à l'université de Cergy-Pontoise. Didaskalia 6: 113-127.

Gunawan. (2009). Pembelajaran berbasis multimedia interaktif untuk meningkatkan kemampuan generik sains calon guru fisika. Jurnal PIJAR MIPA. Vol.4, No. 2, 46-49.

Gunawan. (2013). Model virtual laboratory fisika modern untuk meningkatkan kemampuan generik sains calon guru fisika. Jurnal Pendidikan dan Pembelajaran. Vol.20, No. 1.

Hartono, A. (2006). Perkembangan peserta didik. Jakarta: PT. Asdi Mahasatya.

Henry M. (2001). Notion de modèle et modélisation dans l'enseignement in Henry M. (Ed.) Autour de modélisation en probabilité (149-159). Besançon: Commission inter-IREM Statistique et Probabilité.

Hestenes, D. (1987). Toward a modelling theory of physics instruction. American Journal of Physics, 55(5), 440-454.

Holmquist, M., \& Lingefjärd, T. (2003). Mathematical modeling in teacher education. In Q. Ye, W. Blum, S. K. Houston, \& Q. Jiang (Eds.), Mathematical Modeling in Education and Culture ICTMA 10: Applications in Science and Technology (pp. 197-208). Horwood: Chichester.

Koballa, T.R \& Chiappetta. E.L. (2010). Science instruction in the middle and secondary schools. USA: Pearson Education.

Kolb, A. Y., \& Kolb, D. A. (2005). Learning style and learning spaces: enhancing experiential learning in higher education. Academy of Management Learning \& Education, 4(2), 193-212.

Lederman, N. G., Antink, A., \& Bartos, S. (2014). Nature of science, scientific inquiry, and socioscientific issues arising from genetics: A pathway to developing a scientifically literate citizenry. Science \& Education, 23 (2), 285-302.

Levy, F. \& Murnane, R. J. (2005). The new division of labor: how computers are creating the next job market. Princeton, NJ: Princeton University Press.

Lundgren, L. (1994). Cooperative learning in the science classroom. Macmillan/ McGraw-Hill.

Mulyani, S., Liliasari, L., Wiji, W., Hana, M. N., \& Nursa'adah, E. (2016). Improving students' generic skill in science through chemistry learning using ICT-based media on reaction rate and osmotic pressure material. Jurnal Pendidikan IPA Indonesia, 5(1), 150-156.

National Research Council (NRC). (1996). National science education standarts. Washington, DC: National Academy Press.

OECD. (2016). PISA 2016 assessment and analytical framework: science, reading, mathematic and financial literacy. Paris: PISA OECD Publising.

Ottesen, J. (2001). Do not ask what mathematics can do for modeling. In D. Holton (Ed.), The teaching and learning of mathematics at the university level. An ICMI study (pp.335 - 346). Dordrecht, the Netherlands: Kluwer

Rachmawati. (2013). Pengaruh pendekatan pembelajaran kontekstual terhadap kemampuan koneksi matematis siswa pada materi bangun ruang. Gorontalo: FMIPA Universitas Negeri Gorontalo.

Rahayu, N. (2017). Pengaruh pembelajaran dengan pendekatan inquiry terhadap penguasaan konsep dan scientific skillmateri sistem pencernaan. Jurnal Inovasi Pendidikan IPA, 3(1), 70-77.

Rahman, T. (2016). Kemampuan generik calon guru dalam merencanakan praktikum (studi kasus pada praktikum fisiologi tumbuhan di Online: http://file.upi.edu/Direktori/SPS/PRODI.PENDIDIKAN_IPA/196201151987031TAUFIK_RAHMAN/PROFIL_KEMAMPUAN_GENERIK_AWAL_PERENCANAAN_PRA KTIKUM_CALON_GURU.pdf. 
Roth, W. M., \& Roychoudhury, A. (1993). The development of science process skills in authentic contexts. Journal of Research in Science Teaching, 30(2), 127-152.

Rutherford, F. J., \& Ahlgren, A. (1991). Science for all Americans. Oxford university press.

Sadiqin, I.K., Santoso, U.T., \& Sholahuddin A. (2017). Pemahaman konsep IPA siswa SMP melalui pembelajaran problem solving pada topik perubahan benda-benda di sekitar kita. Jurnal Inovasi Pendidikan IPA, 3(1), 52-62.

Saglam A (2004). Les équations différentielles en mathématiques et en physique: Etude des conditions de leur enseignement et caractérisation des rapports personnels des étudiants de première année d'université à cet objet de savoir. Ph.D. Thesis, Université Joseph Fourier, Grenoble-France.

Sandoval, W. A. (2003). Conceptual and epistemic aspects of students' scientific explanations. Journal of the Learning Sciences, 12 (1), 5-51.

Stewart, V. (2010). A classroom as wide as the world. in curriculum 21: Essential education for a changing world, ed. H. Hayes Jacobs, 97-114. Alexandria, VA: Association for Supervision and Curriculum Development.

Sudarmin. (2006). Pengembangan model pembelajaran kimia organik dan keterampilan generik sains bagi calon guru kimia. Disertasi Pend. IPA. Sekolah Pasca Sarjana UPI Bandung. Tidak diterbitkan.

Suriasumantri, J. S. (2010). Filsafat ilmu. Jakarta: Pestaka Sinar Harapan.

Tivani, I. \& Paidi. (2016). Pengembangan LKS biologi berbasis masalah untukmeningkatkan kemampuan pemecahan masalah dan karakter peduli lingkungan. Jurnal Inovasi Pendidikan IPA, 2(1), 35-45.

Tregidgo, D. \& Ratcliffe, M. (2000). Penggunaan model untuk meningkatkan pembelajaran murid tentang sel. Sekolah Ilmu Review, 81, 53-59.

Tuminaro, J., Redish, E.F. (2004). Understanding students' poor performance on mathematical problem solving in physics. Physics Education Research Conference 2003 Part of the PER Conference series, 720, 113-116. Online: http://www.physics.umd.edu/perg/papers/tuminaro/madison_proceedings. pdf. Diakses tanggal 27 Agustus 2019.

UNESA. (2018) Buku pedoman akademik Unesa. Surabaya: Unesa University Press.

Van Driel, J. H. \& Verloop, N. (1999). Teachers' knowledge of models and modeling in science. International Journal of Science Education, 21, 1141-1153.

Widodo, W. (2011). Pengembangan model pembelajaran "MiKiR" pada perkuliahan fisika dasar untuk meningkatkan keterampilan generik sains dan pemecahan masalah caon guru smk program keahlian tata boga. Disertasi. Sekolah Pascasarjana UPI, tidak diterbitkan.

Widodo, W., Suyanto, T., Setyowati, R.R.N., Martini, Sari, D.A.P., Inzanah. (2018). Model pembelajaran ALLR. Unesa University Press.

Widodo, W., Sari, D.A.P, Martini, dan Suyanto, T. (2019). Strengthening pre-service teachers' character: the application of allr learning model in basic science subject. Advances in Social Science, Education and Humanities Research, 335: 362-367.

Widowati \& Sutimin. (2007). Pemodelan matematika. Semarang: Universitas Diponegoro

Wilmarth, S. (2010). Five socio-technology trends that change everything in learning and teaching. in curriculum 21: Essential education for a changing world, ed. Heidi Hayes Jacobs, 80-96. Alexandria, VA: Association for Supervision and Curriculum Development.

Windschitl, M. (2009). Cultivating 21st century skills in science learners: how systems of teacher preparation and professional development will have to evolve. Presentation given at the National Academies of Science Workshop on 21st Century Skills, Washington, DC.

Yerigan. (2008). Getting active in the classroom. Journal of College Teaching \& Learning, 5(6): 20-24.

Zitzewitz, P.W. (1999). Glencoe physics. New York: McGraw-Hill. 